\title{
Global economic sanctions and export survival: Evidence from cross-country data
}

\author{
Ha Thanh Le
}

\section{A B S T R A C T}

Objective: The aim of the article is to study the relationship between global economic sanctions and export survival. We also investigate the moderating roles of international linkages in the nexus of sanctions and export survival.

Research Design \& Methods: While we employ the new data base of the Global Sanctions Data Base introduced by Felbermayr et-al. (2020), export survival rate is defined as the ratio of the number of survivors to the entrants. We apply the structural gravity model combining the dyad panel dataset of 66 countries during the 1997-2014 period.

Findings: We find the adverse effects of global economic sanctions on export survival. The marginal effects of sanctions become more sizable if there is a longer distance between the sender and the target country. By contrast, the adverse effects of global sanctions can be alleviated if the target country participates in global value chains or global bank linkages.

Implications \& Recommendations: The findings of our study provide vital insights to help policy makers to improve the export performance of countries facing global sanctions.

Contribution \& Value Added: This article is the first to investigate the effects of economic sanctions on export survival. The moderating roles of international linkages in this nexus are described in this study.

\begin{tabular}{llll}
\hline $\begin{array}{l}\text { Article type: } \\
\text { Keywords: }\end{array}$ & research article & \\
JEL codes: & global economic sanctions; export survival; global value chains; global bank linkages \\
\multicolumn{1}{c}{ Received: 21 May 2021 } & Revised: 20 June 2021 & Accepted: 4 September 2021 \\
\hline
\end{tabular}

\section{Suggested citation:}

Le, H.T. (2022). Global Economic Sanctions and Export Survival: Evidence from cross-country data. Entrepreneurial Business and Economics Review, 10(1), 7-22. https://doi.org/10.15678/EBER.2022.100101

\section{INTRODUCTION}

Current international trade is characterized by a low rate of export survival (Besedes \& Prusa, 2006a, 2006b, 2011; Brenton et al., 2009). As starting export, export performance and maintaining export relationships are all important issues in the international trade, it is imperative to explore the driving forces of this low survival rate. Prior scholars indicate that factors such as trade credit, global value chains (Díaz-Mora et al., 2018; Turkan, 2019) and others significantly determine nation's export survival rate. However, the literature has remained silent on the association between global economic sanctions (GESs) and export survival thus far. A strong interdependency between countries for military assistance, foreign direct investment (FDI), trade inflows or financial reserves (IMF, 2009) further fuels highly integrated international environments. This puts domestic economies at a high risk of adverse macroeconomic policies, for example a reduction in FDI or aid. As a result, these economies are exposed as being vulnerable in the increasingly integrated world. The network of international interdependencies and the vulnerability of less developed nations result in the application of "sanctions." Since GESs have become increasingly used over time (Felbermayr et al., 2020), there is a call for research on the relationship between GESs and export survival. 
As Felbermayr et al. (2020) and Folch (2010) revealed, GESs take various forms, such as the withdrawal of arms and military assistance, trade restrictions (i.e. partial, or total embargoes), financial or economic blockades (i.e. asset freeze), and travel bans. These are triggered by a wide variety of economic, political, and environmental policies or they serve multiple purposes (proactive, punitive or demonstrative). According to Folch (2010), the actions or specific methods of intervention are based on coercive measures (threats) against a sanctioned party (a target country) by one country (a sanctioning country or a sender, e.g. the United States), a coalition of countries (e.g. the European Union), or international organisations (e.g. the United Nations). The primary goal of GESs is to punish or change a specific policy or behaviour of the target country.

Since the GESs serve as a means of dispute settlement for peaceful conflict resolution, they receive substantial appreciation in the context of international negotiation. However, there has been a serious warning against GESs and the way they are used to fulfil the original purposes. Many scholars are concerned about the consequences of GESs, such as their negative effect on life expectancy and infant mortality (Ali Mohamed \& Shah, 2000; Daponte \& Garfield, 2000), on human rights and democracy levels (Peksen \& Drury, 2010), the availability of food and drinking water (Cortright \& Lopez, 2000), and the access to health care and medicine (Garfield, 2002). In addition to their social consequences, the economic consequences of GESs have also gained attention from scholars. Very few studies demonstrate the adverse effects of GESs on the flow of FDI (Barry \& Kleinberg, 2015). Our study contributes to the extant literature by investigating the relationship between GESs and export survival.

In this article, we apply a modified gravity model to examine the association between GESs and export survival rate. To the best of our knowledge, this article is the first to study this issue. While the interdependence between nations through international trade is one of the bases for the application of GESs, it is important to analyse the impacts of GESs on the probability that a target country will remain in foreign markets as a way to evaluate the effectiveness of GESs. Moreover, our study advances the literature by indicating a channel through which sanctioned states can attenuate the adverse effects of GESs. For this purpose, we test the moderating role of international linkage participation in this relationship. To perform these tests, we employ the dyad panel dataset covering 66 countries from 1997 to 2014 and the new database from Felbermayr et al. (2020). The findings of this paper are expected to provide insightful lessons for policymakers in both the sanctioning and sanctioned state. Regarding the senders, our study provides important policy implications that could be used to improve the success rate of GESs in punishing the target country's international trade. Regarding the target country, this research indicates a strategic way to help a country to improve its export performance and survive longer in foreign markets.

The rest of the paper proceeds as follows. Section two will provide a review of the relevant literature and develops the hypotheses. Section three will present the model, data, and estimation method. Section four will outline the empirical results and discussion. Section five will conclude the paper.

\section{LITERATURE REVIEW}

In this article, we investigate the drivers of export survival rate. Our main focus is on the effects of GESs. Hence, this article is closely related to two strands of the literature. The first strand consists of papers studying the relationship between GESs and export survival, and the second is papers explaining the moderating roles of global linkage participation on the association between GESs and export survival.

\section{Global Economic Sanctions and Export Survival}

We contend that the trade between the source and target country may be affected by the GESs through their impact on factor endowments. Therefore, the export survival rate is expected to be influenced by the GESs. The reasons are as follows. Firstly, based on the Heckscher-Ohlin model of international trade, countries should trade more if there are larger differences in their factor endowment (Ghosh \& Yamarik, 2005; Debaere, 2003; Romalis, 2004). It is most likely that senders imposing economic sanctions on other countries are developed countries, while the target countries are less developed. The GESs further expand the "distance" between senders and target countries in terms of factor 
endowments. In particular, the mobility of natural resources between these countries may be disrupted by trade sanctions, such as trade barriers, tariffs, or trading bans. Similarly, financial sanctions hinder the capital inflows of the target country by restricting the provision of certain financial services or access to credit. Therefore, these sanctions expand the distance between the sender and the target country, discourage firms from participating in global trade, or reduce their probability of remaining in international markets. Secondly, we contend that the GESs create difficulties for both the exports and imports of senders and the target countries. According to Hufbauer et al. (2009), the commercial and financial ties between the sender and target country are disrupted due to the penalties against targeted states through either trade or financial sanctions.

Furthermore, physical capital plays a critical role in the success of a country's exports. The government uses the budget to invest in public infrastructure, for example roads and transport infrastructures, or information and communications technology (ICT) infrastructures, which may reduce trade costs and improve supply capacity. These advantages enhance a country's participation and success in foreign markets. For many countries, FDI is regarded as the main financial source of these investments. Moreover, FDI helps receiving countries to enhance their comparative advantages through technology transfers. However, GESs potentially restrict future economic access to the target country, making speculation about current and future investment opportunities there gloomy. In turn, the risk disincentivises global investors (Jensen, 2008; Li, 2009; Biglaiser \& Staats, 2010), thus reducing the inward flows of FDI into the target states (Janeba, 2002). Accordingly, GESs potentially create disadvantages for the sanctioned country's exports.

Based on our discussion, we posit that:

H1: Being sanctioned in the previous year reduces the probability of export survival in the current year.

\section{Moderating Roles of Global Linkage Participation}

In this article, we contend that participation in global linkages such global supply chains (GVCs) and global bank linkages (GBLs) may help countries to attenuate the adverse effects of GESs. There are reasons to support our belief. Firstly, joining global supply chains by trading parts and components creates longlived relationships and leads to higher survival rates (Obashi, 2010; Corcoles et al., 2015). Deep participation in the GVC helps firms to obtain a more stable trade relationship (Díaz-Mora et al., 2018), which reduces uncertainty and enhances the trust and reliability of trade partners. Moreover, a positive extension of export duration stems from product quality, product diversity, and investment in asset-pricing improvements for firms integrated into the GVC (Zhu et al., 2019). These raise a country's survivability when exploring the international markets, even if it faces a GES or any difficulties created by GES. Secondly, joining global bank linkages mitigates the export risk from information asymmetries or difficulties in payment enforcement (Hale et al., 2013). As revealed by Olsen (2013) and Niepmann and SchmidtEisenlohr (2017), cross-border bank linkages can also enforce or guarantee payments. Furthermore, information on creditworthiness can be passed from banks in the sanctioning country to other banks in the target country, which are connected. Then this information may be passed to exporting firms. Hence, the information asymmetries leading to export risks can reduce, and this can improve the export survival rate. Thirdly, the global linkages also help countries to promote the inward flows of FDI. Hale (2012) and Poelhekke (2015) provide empirical evidence on the positive association between global linkages and the FDI flow. The global linkages reduce information asymmetries, which makes FDI investors more confident in their investments. As a consequence, the adverse impacts of GESs on FDI flows can be mitigated, and therefore the target countries are more likely to enjoy the benefits and comparative advantages of FDI. These countries can then compete with each other and survive better in foreign markets. By studying the effects of foreign value added within GVCs on wage, Partekka and Wolszczak-Derlacz (2017) also highlight the importance of global linkage participation.

Based on our discussion, we posit that:

H2: The effects of global economic sanctions on export survival are weaker if a country joins international linkages. 
To the best of our knowledge, there is no article exploring the nexus of sanction and export survival, especially across countries. Recently, a few studies have investigated the influences of sanctions on firm performance (Ahn \& Ludema, 2020) or the exporting behaviour of firms (Crozet et al., 2021). Other studies, such as Bellora and Fontagné (2020) and Mao and Görg (2020), explore the impacts of the recent USChina trade war on the GVC, but their country-specific research only focuses on a typical form of sanction. Our paper contributes to the current literature in the following dimensions. Firstly, we are the first to investigate the direct effects of sanctions on export survival probability of firms by using cross-country data. Secondly, Peksen (2019) argues that the success of sanctions relies on the international relationship between sanctioning and sanctioned states, but there is no paper incorporating the moderating effects of international linkages on the association between sanctions and export survival. Therefore, we explore the moderating roles of international linkages on the sanction-export survival nexus.

\section{RESEARCH METHODOLOGY}

We specify the following model to examine the impacts of GESs on export survival:

$$
S U R_{i j t}^{p}=\beta_{0}+\beta_{1} \text { Sanction }_{i, t-1}+\beta_{2} \text { CONTROL }_{i j, t-1}+v_{t}+\lambda_{i}+\gamma_{j}+\varepsilon_{i j t}
$$

in which superscripts $i$ and $j$ denote the source and target country, and $t$ denotes year while $v_{t}, \lambda_{i}$, and $\gamma_{j}$ capture year, source-country-fixed and target-country-fixed, respectively. Moreover, $\varepsilon_{i j t}$ is the error term. The dependent variable, $S U R^{p}$, is an export survival rate measure. We denote FSUR, SSUR, and $T S U R$ as the ratio of the numbers of first-year, second-year and third-year survivors to the number of entrants in year $t$, respectively. The detailed measures of FSUR, SSUR, and TSUR are provided in Appendix A. The key variable, Sanction ${ }_{i j t}$, captures all bilateral sanctions of country $i$ imposed on country $j$ in year $t$. We employ the Global Sanctions Data Base introduced by Felbermayr et al. (2020). This dataset classifies sanctions into different types (i.e. trade versus financial sanctions) and only concen-

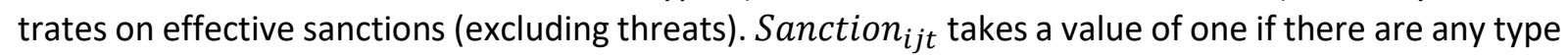
of sanctions between country $i$ and $j$, and 0 otherwise.

In addition to the sanction variable, we also incorporate a set of other control variables, CONTROL. In particular, the GVC plays a critical role in the probability of export survival. While trade in parts and components generates a longer-lived relationship and better survival rates (Corcoles et al., 2015), Turkan (2016) provides empirical evidence to advocate the role of GVC in export survival in Turkey. We follow Koopman et al. (2010) to classify GVC participation by the source of the value added incorporated in exports, looking both backward and forward from the view of a reference country (country $A$ ). Backward participation (Backward) is the value added of country $B$, contained in exports from country A to country B; forward participation (Forward) is the value added of country A, which is embodied as intermediate goods that support the production of exports from country $B$ to country $C$. The sum of both Backward and Forward is the total GVC (GVCtotal). The GVC participation data is taken from the OECD TiVA database. The variable $G D P_{i}$ is the gross domestic product of recipient country $j$. This variable is available from the World Bank database. As contended by Brenton et al. (2009), the market size captured by this variable is anticipated to determine export survival. The bilateral distance between the home and host country $(I n D)$ is also added into the model. According to Stirbat et al. (2015), this variable may be negatively associated with export survival since trading over long distance may lead to impediments such transportation costs. This variable is taken from the Centre d'Études Prospectives et d'Informations Internationales (CEPII). The dummy variable FTA takes the value of one if country $i$ and $j$ belong to the same FTA and 0 otherwise. The Herfindahl-Hirschman index ( $\mathrm{HHI}$ ), which measures the market concentration in the destination market. The $\mathrm{HHI}$ is a measure of diversification and it takes any value between 0 and 1 , with higher values representing a greater concentration in the destination market. Export survival may be negatively affected by $\mathrm{HHI}$, as argued by Corcoles et al. (2015). The variables Value and Share are respectively the export value per entrant and the share of new products in the total export value of incumbents. Besedes and Prusa (2006) reveal that the former, which captures firms' confidence level, may impact their trade survival as the greater the confidence level, the more durable the relationship is. The latter reflects experience with a product. As contended by Stirbat 
et al. (2015), the survival rate could be dampened by this variable because exporting subsequent products is less costly and risky than exporting new products. We collect the data for variables SUR, HHI, Value, and Share from Exporter Dynamics Database of The World Bank at country-destination-year level. The choice of explanatory variables is based on the literature on export survival and the availability of data. In this article, we attempt to incorporate as many explanatory variables as possible, based on the data availability in the structural gravity model.

After merging and cleaning the data, the sample contains roughly 5500 country-year observations from 66 countries $^{1}$ during the period of 1997-2014. The reasons for our sample selection are as follows. Our key explanatory variable, Sanction, is sourced from the new database of the Global Sanctions Data Base introduced by Felbermayr et al. (2020). However, the data on economic sanctions are only available from 1950 to 2016. The other sanction data are not suitable for use in the gravity model due to their lack of continuity and completeness. The lack of data on sanctions is the biggest challenge for researchers who wish to explore the impacts of sanctions. Furthermore, one of our main concerns is examining the moderating roles of international linkages such as GVCs and global bank linkage in the nexus between sanctions and export survival. These variables are only available until 2014. Some gravity variables face the same challenge. After cleaning and merging all the sources of data, our database covers 66 countries during the 1997-2014 period. The statistical descriptions of all the included variables are presented in Table 1. As shown in the table, the average survival rate of firms in their first year of exporting is roughly $40 \%$ and this diminishes to $24 \%$ and $17 \%$ in the second and third year, respectively. The average number of bilateral sanctions implemented is quite small (roughly $3 \%$ ) in our sample.

Table 1. Statistical summary

\begin{tabular}{|l|c|c|c|c|c|}
\hline \multicolumn{1}{|c|}{ Variable } & Obs & Mean & Std. Dev. & Min & Max \\
\hline FSUR & 5495 & 0.40 & 0.12 & 0.00 & 1.00 \\
\hline SSUR & 4506 & 0.24 & 0.11 & 0.00 & 1.00 \\
\hline TSUR & 3715 & 0.17 & 0.09 & 0.00 & 1.00 \\
\hline Sanction & 97756 & 0.02 & 0.15 & 0.00 & 1.00 \\
\hline GVCtotal & 6646 & 0.62 & 1.11 & 0.00 & 17.98 \\
\hline Backward & 6646 & 0.36 & 0.83 & 0.00 & 15.16 \\
\hline Forward & 6646 & 0.25 & 0.51 & 0.00 & 5.90 \\
\hline Link & 97732 & 0.10 & 0.41 & 0.00 & 5.31 \\
\hline GDP & 6646 & 26.64 & 1.52 & 23.27 & 30.45 \\
\hline InD & 6646 & 8.61 & 0.96 & 5.08 & 9.88 \\
\hline FTA & 6646 & 0.47 & 0.50 & 0.00 & 1.00 \\
\hline HHI & 6625 & 0.14 & 0.18 & 0.00 & 1.00 \\
\hline InValue & 6309 & 0.23 & 0.46 & 0.00 & 11.18 \\
\hline Share & 6306 & 0.17 & 0.10 & 0.00 & 1.00 \\
\hline
\end{tabular}

Source: own study.

The correlations between explanatory variables are summarised in Table 2. Since the correlation coefficients are all lower than 0.8 , there should be no problem of multicollinearity in our regressions.

We firstly regress the set of export survival probability on Sanction and the control variables. To examine the moderating roles of global linkages in the relationship between sanctions and export survival probability, we suggest the following model:

$$
\begin{aligned}
\operatorname{SUR}_{i j t}^{p}=\varphi_{0}+ & \varphi_{1} \text { Sanction }_{i, t-1}+\varphi_{2} \text { CONTROL }_{i j, t-1}+\varphi_{3} G L_{i, t-1}+\varphi_{4} G L_{i, t-1} * \\
& * \text { Sanction }_{i, t-1}+v_{t}+\lambda_{i}+\gamma_{j}+\varepsilon_{i j t}
\end{aligned}
$$

in which $G L_{i, t}$ denotes the global linkages, which are either GVCs or GBLs. The sign and magnitude of the interactions between $G L_{i, t}$ and Sanction $_{i, t}$ reflect the moderating roles of global linkages.

\footnotetext{
${ }^{1}$ A description of the countries included in the sample is provided in Table A.1 in the Appendix.
} 
Table 2. Correlation matrix

\begin{tabular}{|l|c|c|c|c|c|c|c|c|}
\hline \multicolumn{1}{|c|}{ Variable } & Sanction & GVCtotal & GDP & InD & FTA & HHI & Value & Share \\
\hline Sanction & 1 & & & & & & & \\
\hline GVCtotal & 0.0413 & 1 & & & & & & \\
\hline GDP & 0.140 & 0.332 & 1 & & & & & \\
\hline InD & 0.0379 & -0.445 & 0.0971 & 1 & & & & \\
\hline FTA & -0.0799 & 0.225 & -0.146 & -0.637 & 1 & & & \\
\hline HHI & -0.0360 & -0.251 & -0.200 & 0.308 & -0.184 & 1 & & \\
\hline InValue & -0.00210 & 0.167 & 0.115 & -0.0111 & 0.00434 & 0.0933 & 1 & \\
\hline Share & 0.103 & 0.00806 & 0.130 & -0.0129 & -0.00750 & -0.0825 & -0.138 & 1 \\
\hline
\end{tabular}

Source: own study.

\section{RESULTS AND DISCUSSION}

\section{Baseline Results}

We report the estimation results of Equation (1) in Table 3, to examine the effects of GES in year $t-1$ on the export survival in year $t$. The standard errors are clustered on country-pair and both country and year fixed effects are considered in all models. The main findings will be conveyed in this section. Firstly, the coefficients of Sanction are statistically significant and negative, as expected. The results imply that the GES decreases the survival probability of export firms in the target country. Our empirical results are consistent with the argument of Felbermayr et al. (2020) that economic sanctions adversely affect the exporting value of a country. Moreover, Chen and Garcia (2016) reveal that importing activities decrease under the impacts of sanctions. Our study emphasises that sanctioned states are more likely to leave foreign markets than non-sanctioned ones. Secondly, the results indicate that the effects of GES become less sizable after one year and two years of survival, at $1 \%$ level of significance, as reported in Columns 1 to 3 of Table 3 . In other words, the impacts of sanctions decline over time for exporting firms with experience and success in foreign markets. There are plausible explanations for this finding. The success of exporting in the first year may boost trust and reliability between exporting firms and their training partners (Chaney, 2014), thus reinforcing their relationship and increasing the probability of surviving in foreign markets in the following years.

Regarding the other control variables, our study confirms that the distance between sender and target country is negatively associated with the survival rate of exporters in the target country. The literature demonstrates that exporting firms may leave foreign markets due to the high transaction costs created by the long distances between two trading partners. By contrast, this risk of failure can reduce through the proximity and share of commons (Petersen \& Rajan, 2002). To conduct a robustness check on the effects of distance, we consider different types of distance, including both physical and "soft" distances and investigating how the distance moderates the association between GES and export survival. To perform this, we add the interactions between this type of distance and the sanction variable in Equation (1) and report the results in Table 4. The four types of distance are the distance in financial market development and tax system, and cultural and physical distance. Regarding distance in financial market development, we employ a composite index of financial market development based on nine components, which capture the stability, depth and efficiency of financial systems, and financial access (as in Donaubauer et al., 2020). We measure the distance in the tax system by using the data from the World Tax Database augmented by data published by the Heritage Foundation. Regarding the cultural distance, we base it on Schwartz's (2006) method of measuring cultural distance for different waves of the World Value Surveys. Our results demonstrate the statistically significant and negative coefficients of these interactions. The risk of failure in foreign markets can be accelerated by the distance. The distance also signifies the marginal effects of sanctions on the probably of survival. In other words, the effects of GES become stronger for firms operating in a country that has a long "distance" from its trading partners. 
Table 3. Baseline results

\begin{tabular}{|l|c|c|c|}
\hline \multirow{2}{*}{ VARIABLES } & First-year Survivor & Second-year Survivor & Third-year Survivor \\
\cline { 2 - 4 } & $\mathbf{( 1 )}$ & $\mathbf{( 3 )}$ & $\mathbf{( 5 )}$ \\
\hline Sanction & $-0.0440^{* * *}$ & $-0.0370^{* * *}$ & $-0.0350^{* * *}$ \\
& $(0.0134)$ & $(0.0143)$ & $0.0131)$ \\
\hline GVCtotal & 0.00286 & 0.00471 & $(0.00308)$ \\
\hline GDP & $(0.00303)$ & $(0.00313)$ & -0.0161 \\
& 0.00255 & 0.00667 & $(0.0123)$ \\
\hline InD & $(0.0100)$ & $(0.0103)$ & $-0.0335^{* * *}$ \\
& $-0.0431^{* * *}$ & $-0.0383^{* * *}$ & $(0.00357)$ \\
\hline FTA & $(0.00416)$ & $(0.00380)$ & $0.0120^{* *}$ \\
& $3.10 \mathrm{e}-05$ & $0.0122^{* *}$ & $(0.00486)$ \\
\hline HHI & $(0.00624)$ & $(0.00574)$ & 0.00226 \\
& $-0.0259 *$ & -0.0131 & $(0.0134)$ \\
\hline InValue & $(0.0157)$ & $(0.0148)$ & 0.00686 \\
& $0.0144^{* * *}$ & $0.0110^{* * *}$ & $(0.00427)$ \\
\hline Share & $(0.00331)$ & $(0.00392)$ & $-0.109 * *$ \\
& $-0.168 * * *$ & $-0.154 * * *$ & $(0.0501)$ \\
\hline Constant & $(0.0428)$ & $(0.0432)$ & $0.972^{* * *}$ \\
\hline Observations & $0.727^{* *}$ & 0.400 & $(0.377)$ \\
\hline Country FE & $(0.304)$ & $(0.314)$ & 3683 \\
\hline Year FE & 5445 & 4464 & YES \\
\hline R2 & YES & YES & 0.480 \\
\hline
\end{tabular}

Robust standard errors in parentheses; ${ }^{* *} \mathrm{p}<0.01,{ }^{* *} \mathrm{p}<0.05, * \mathrm{p}<0.1$.

Source: own study.

We also find that exporters are more likely to survive longer if there are preferential trade agreements. According to Caporale et al. (2009) and Hannan (2016), FTA provides incentives and advantages to trading partners, thus helping exporting firms to secure more export gains and compete with others in foreign markets. The estimation of Equation (1) also reveals the negative effect of the HHI on survival rate. The finding implies that firms' export performance can be improved if they enter into transactions with different trading partners (Funke \& Ruhwedel, 2001). Diversification of trading partners can reduce the risk and help firms to survive longer in foreign markets. However, this variable is only statistically significant for the sample of first-year survivors; we do not find similar evidence for the sample of second-year and third-year survivors. This fact suggests the further implications that new and young exporters should diversify their trading partners, while firms that have existed for a long time in the market should focus on developing their relationships with their strategic partners.

Regarding the remaining variables, our results are aligned with those of prior works. In particular, initial trust in counterparts and in the sustainability of their trade relationships, captured by the initial export value of the entrant (InValue), enhances the probability of surviving in foreign markets. The positive sign of InValue is consistent with Besedes (2008) and Impulliti et al. (2013). Similarly, we also find a negative association between the share of new products in the total export value of surviving entrants (Share) and export survival, as in Esteve-Pérez et al. (2013). 
Table 4. The distance in financial market development, tax system, cultural and physical distance

\begin{tabular}{|c|c|c|c|c|c|c|c|c|c|c|c|c|}
\hline \multirow{3}{*}{ VARIABLES } & \multicolumn{4}{|c|}{ First-year Survivor } & \multicolumn{4}{|c|}{ Second-year Survivor } & \multicolumn{4}{|c|}{ Third-year Survivor } \\
\hline & $\begin{array}{c}\text { Financial } \\
\text { Development }\end{array}$ & $\begin{array}{c}\text { Tax } \\
\text { System }\end{array}$ & Culture & $\begin{array}{l}\text { Physical } \\
\text { Distance }\end{array}$ & $\begin{array}{c}\text { Financial } \\
\text { Development }\end{array}$ & $\begin{array}{c}\text { Tax } \\
\text { System }\end{array}$ & Culture & $\begin{array}{l}\text { Physical } \\
\text { Distance }\end{array}$ & $\begin{array}{c}\text { Financial } \\
\text { Development }\end{array}$ & $\begin{array}{c}\text { Tax } \\
\text { System }\end{array}$ & Culture & $\begin{array}{l}\text { Physical } \\
\text { Distance }\end{array}$ \\
\hline & (1) & (2) & (3) & (4) & (5) & (6) & (7) & (8) & (9) & (10) & (11) & (12) \\
\hline Sanction & $\begin{array}{l}-0.0113 \\
(0.0154)\end{array}$ & $\begin{array}{c}0.0906 \\
(0.0559)\end{array}$ & $\begin{array}{c}0.0176 \\
(0.0841)\end{array}$ & $\begin{array}{l}0.0842^{*} \\
(0.0468)\end{array}$ & $\begin{array}{l}-0.0161 \\
(0.0171)\end{array}$ & $\begin{array}{c}0.0392 \\
(0.0489)\end{array}$ & $\begin{array}{l}-0.0697 \\
(0.188)\end{array}$ & $\begin{array}{c}0.122^{* * *} \\
(0.0427)\end{array}$ & $\begin{array}{l}-0.0191 \\
(0.0160)\end{array}$ & $\begin{array}{c}0.0186 \\
(0.0582)\end{array}$ & $\begin{array}{l}-0.0750 \\
(0.112)\end{array}$ & $\begin{array}{c}0.0441 \\
(0.0532)\end{array}$ \\
\hline Difference & $\begin{array}{c}0.0110^{* * *} \\
(0.00340)\end{array}$ & \begin{tabular}{|c|}
0.000479 \\
$(0.000671)$
\end{tabular} & $\begin{array}{l}-0.0754 \\
(0.0495)\end{array}$ & $\begin{array}{c}0.00723 * * * \\
(0.00113)\end{array}$ & $\begin{array}{c}0.0118^{* * *} \\
(0.00317)\end{array}$ & $\begin{array}{c}0.000274 \\
(0.000586) \\
\end{array}$ & $\begin{array}{l}-0.112^{* *} \\
(0.0458)\end{array}$ & $\begin{array}{c}0.00549 * * * \\
(0.00119)\end{array}$ & $\begin{array}{c}0.00934^{* * *} \\
(0.00341)\end{array}$ & $\begin{array}{c}0.000552 \\
(0.000615)\end{array}$ & \begin{tabular}{|c|}
-0.0585 \\
$(0.0434)$ \\
\end{tabular} & $\begin{array}{r}0.00488^{* * *} \\
(0.00121)\end{array}$ \\
\hline Sanction*Difference & $\begin{array}{l}-0.0157^{* *} \\
(0.00638) \\
\end{array}$ & \begin{tabular}{|c|}
$-0.00432 *$ \\
$(0.00232)$ \\
\end{tabular} & $\begin{array}{c}-0.293 \\
(0.660) \\
\end{array}$ & \begin{tabular}{|c|}
$-0.0123 * *$ \\
$(0.00523)$ \\
\end{tabular} & $\begin{array}{l}-0.0133^{* *} \\
(0.00558) \\
\end{array}$ & \begin{tabular}{|c|}
-0.00217 \\
$(0.00184)$ \\
\end{tabular} & $\begin{array}{c}0.254 \\
(1.327) \\
\end{array}$ & \begin{tabular}{|c|}
$-0.0165^{* * *}$ \\
$(0.00454)$ \\
\end{tabular} & $\begin{array}{c}-0.0148^{*} \\
(0.00872) \\
\end{array}$ & \begin{tabular}{|c|}
-0.00132 \\
$(0.00223)$ \\
\end{tabular} & \begin{tabular}{|c|}
0.314 \\
$(0.803)$ \\
\end{tabular} & $\begin{array}{c}-0.00823 \\
(0.00568) \\
\end{array}$ \\
\hline GVCtotal & $\begin{array}{c}0.00261 \\
(0.00303) \\
\end{array}$ & $\begin{array}{c}0.00310 \\
(0.00320) \\
\end{array}$ & $\begin{array}{c}0.00136 \\
(0.00195) \\
\end{array}$ & $\begin{array}{l}-0.000612 \\
(0.00260) \\
\end{array}$ & $\begin{array}{c}0.00442 \\
(0.00326)\end{array}$ & $\begin{array}{c}0.00425 \\
(0.00319) \\
\end{array}$ & $\begin{array}{c}0.00168 \\
-0.00239 \\
\end{array}$ & $\begin{array}{c}0.00143 \\
(0.00303)\end{array}$ & $\begin{array}{c}0.00788^{* * *} \\
(0.00279) \\
\end{array}$ & $\begin{array}{c}0.00714^{* *} \\
(0.00283) \\
\end{array}$ & \begin{tabular}{|c|}
0.00137 \\
$(0.00418)$ \\
\end{tabular} & $\begin{array}{c}0.00255 \\
(0.00370) \\
\end{array}$ \\
\hline GDP & $\begin{array}{l}-0.00145 \\
(0.00887)\end{array}$ & $\begin{array}{c}-0.00283 \\
(0.0102)\end{array}$ & \begin{tabular}{|c|}
-0.0163 \\
$(0.0137)$ \\
\end{tabular} & \begin{tabular}{|c|}
-0.00207 \\
$(0.00909)$ \\
\end{tabular} & $\begin{array}{c}-0.0108 \\
(0.00830)\end{array}$ & $\begin{array}{c}-0.0159 \\
(0.0110) \\
\end{array}$ & \begin{tabular}{|c|}
-0.00280 \\
$(0.0132)$ \\
\end{tabular} & \begin{tabular}{|c|}
-0.00444 \\
$(0.0101)$ \\
\end{tabular} & $\begin{array}{l}-0.0177^{* *} \\
(0.00896)\end{array}$ & \begin{tabular}{|c|}
$-0.0288^{*}$ \\
$(0.0150)$
\end{tabular} & \begin{tabular}{|c|}
-0.00847 \\
$(0.0121)$ \\
\end{tabular} & $\begin{array}{l}-0.0214^{*} \\
(0.0127)\end{array}$ \\
\hline $\ln D$ & $\begin{array}{c}-0.0425 * * * \\
(0.00430) \\
\end{array}$ & \begin{tabular}{|c|}
$-0.0430 * * *$ \\
$(0.00449)$ \\
\end{tabular} & $\begin{array}{c}-0.0165 * * * \\
(0.00568) \\
\end{array}$ & \begin{tabular}{|c|}
$-0.0759 * * *$ \\
$(0.00662)$ \\
\end{tabular} & $\begin{array}{c}-0.0382 * * * \\
(0.00406) \\
\end{array}$ & \begin{tabular}{|c}
$-0.0365 * * *$ \\
$(0.00404)$ \\
\end{tabular} & \begin{tabular}{|c|}
$-0.0144 * * *$ \\
$(0.00522)$ \\
\end{tabular} & \begin{tabular}{|c|}
$-0.0632 * * *$ \\
$(0.00662)$ \\
\end{tabular} & $\begin{array}{c}-0.0314 * * * \\
(0.00365) \\
\end{array}$ & \begin{tabular}{|c|}
$-0.0300 * * *$ \\
$(0.00365)$ \\
\end{tabular} & \begin{tabular}{|c|}
$-0.0118 * *$ \\
$(0.00488)$ \\
\end{tabular} & $\begin{array}{r}-0.0556 * * * \\
(0.00704) \\
\end{array}$ \\
\hline FTA & $\begin{array}{r}-0.000432 \\
(0.00619) \\
\end{array}$ & $\begin{array}{c}0.00503 \\
(0.00724) \\
\end{array}$ & $\begin{array}{c}0.00443 \\
(0.00677) \\
\end{array}$ & \begin{tabular}{|c|}
0.00188 \\
$(0.00575)$ \\
\end{tabular} & $\begin{array}{c}0.0153^{* * *} \\
(0.00587)\end{array}$ & \begin{tabular}{|c|}
$0.0186 * * *$ \\
$(0.00597)$ \\
\end{tabular} & \begin{tabular}{|l|}
$0.0126^{* *}$ \\
$(0.00637)$ \\
\end{tabular} & $\begin{array}{l}0.0119 * * \\
(0.00542) \\
\end{array}$ & $\begin{array}{c}0.0138 * * * \\
(0.00524)\end{array}$ & $\begin{array}{c}0.0145^{* * *} \\
(0.00540) \\
\end{array}$ & \begin{tabular}{|l|}
$0.0129 * *$ \\
$(0.00558)$ \\
\end{tabular} & $\begin{array}{l}0.0120^{* *} \\
(0.00486) \\
\end{array}$ \\
\hline $\mathrm{HHI}$ & $\begin{array}{c}-0.0499 * * * \\
(0.0158)\end{array}$ & $\begin{array}{c}-0.0504^{* * *} \\
(0.0172)\end{array}$ & $\begin{array}{c}-0.0405 \\
(0.0280) \\
\end{array}$ & \begin{tabular}{|c|}
$-0.0388^{* * * *}$ \\
$(0.0149)$
\end{tabular} & $\begin{array}{c}-0.0239 * \\
(0.0133)\end{array}$ & $\begin{array}{c}-0.0303^{* *} \\
(0.0144)\end{array}$ & $\begin{array}{c}-0.0150 \\
(0.0269)\end{array}$ & $\begin{array}{c}-0.0334^{* *} \\
(0.0144)\end{array}$ & $\begin{array}{c}-0.00548 \\
(0.0145)\end{array}$ & $\begin{array}{c}-0.0122 \\
(0.0152)\end{array}$ & \begin{tabular}{|l|}
0.00833 \\
$(0.0231)$ \\
\end{tabular} & $\begin{array}{c}-0.0297^{* *} \\
(0.0137)\end{array}$ \\
\hline InValue & $\begin{array}{c}0.0138^{* * *} \\
(0.00446)\end{array}$ & $\begin{array}{c}0.0129 * * * \\
(0.00422)\end{array}$ & $\begin{array}{c}0.00816 * * \\
(0.00360)\end{array}$ & \begin{tabular}{|c|}
$0.0114 * * *$ \\
$(0.00394)$ \\
\end{tabular} & $\begin{array}{c}0.0146 * * * \\
(0.00433)\end{array}$ & $\begin{array}{c}0.0193 * * * \\
(0.00338) \\
\end{array}$ & $\begin{array}{c}0.00665 \\
(0.00581) \\
\end{array}$ & $\begin{array}{l}0.0115^{* *} \\
(0.00475)\end{array}$ & $\begin{array}{l}0.00828^{*} \\
(0.00430)\end{array}$ & $\begin{array}{c}0.0169 * * * \\
(0.00490) \\
\end{array}$ & $\begin{array}{l}0.000341 \\
(0.00416) \\
\end{array}$ & $\begin{array}{c}0.00760 \\
(0.00603)\end{array}$ \\
\hline Share & $\begin{array}{c}-0.351^{* * *} \\
(0.0420)\end{array}$ & $\begin{array}{c}-0.320^{* * *} \\
(0.0440) \\
\end{array}$ & $\begin{array}{c}-0.100^{*} \\
(0.0555) \\
\end{array}$ & $\begin{array}{c}-0.211 * * * \\
(0.0571) \\
\end{array}$ & $\begin{array}{c}-0.281 * * * \\
(0.0322)\end{array}$ & $\begin{array}{c}-0.266^{* * *} \\
(0.0338) \\
\end{array}$ & \begin{tabular}{|c|}
-0.0459 \\
$(0.0459)$ \\
\end{tabular} & $\begin{array}{c}-0.199 * * * \\
(0.0646) \\
\end{array}$ & $\begin{array}{c}-0.239 * * * \\
(0.0319) \\
\end{array}$ & $\begin{array}{c}-0.241^{* * *} \\
(0.0344) \\
\end{array}$ & \begin{tabular}{|c|}
$-0.0809^{*}$ \\
$(0.0430)$ \\
\end{tabular} & $\begin{array}{c}-0.107 \\
(0.0861) \\
\end{array}$ \\
\hline Observations & 3990 & 3675 & 2210 & 4565 & 3260 & 3055 & 1860 & 3713 & 2677 & 2483 & 1571 & 3053 \\
\hline Country FE & YES & YES & YES & YES & YES & YES & YES & YES & YES & YES & YES & YES \\
\hline Year FE & YES & YES & YES & YES & YES & YES & YES & YES & YES & YES & YES & YES \\
\hline R2 & 0.602 & 0.590 & 0.361 & 0.529 & 0.644 & 0.640 & 0.399 & 0.571 & 0.647 & 0.643 & 0.368 & 0.567 \\
\hline
\end{tabular}

Robust standard errors in parentheses; ${ }^{* *} p<0.01,{ }^{* *} p<0.05,{ }^{*} p<0.1$

Source: own study. 


\section{Moderating Roles of Global Value Chains and Global Bank Linkages}

\section{Global Value Chains}

In the previous analysis, we mostly concentrate on factors that signify the marginal effects of GES. In this section, we argue that there are channels that exporters can use to reduce the harmful effects of GES. The first channel is participation in GVCs. To investigate our belief, we follow Koopman et al. (2010) to classify GVCs into Backward and Forward, and we add their interactions and GES into Equation (1). The results are displayed in Table 5. Firstly, Backward, Forward, and GVCtotal (the sum of Backward and Forward) are statistically significant and have the expected positive sign as presented in Columns (2), (4), (5) and (8). Our findings are consistent with Díaz-Mora et al. (2018). However, DíazMora et al. (2018) provide empirical evidence for a more important role for the forward dimension than for the backward one. More importantly, the coefficient of an interaction between Backward and Sanction is statistically significant and positive for the sample of the first-year and second-year survivors. Our finding provides the empirical evidence to support our argument that GVCs (Backward type) can be considered as an effective channel to help exporting firms alleviate the impacts of sanctions. The findings of our study advocate the argument of Peterson (2020) that a better connection to international networks makes the consequences of sanctions less severe.

\section{Global Bank Linkages}

Another channel through which the adverse effects of GES can be attenuated is global bank linkage (GBL). The effects of risk can be mitigated by a higher share of trade finance in a given country (Niepmann \& Schmidt-Eisenlohr, 2017). In this article, we contend that the adverse effects of GES can be alleviated due to the information advantage about the home and host-country firms. Therefore, exporting firms are more likely to survive in foreign markets. To investigate our prediction, we incorporate an interaction between GBL and GES. The GBL, LINK, measures the aggregate number of bank linkages of country $i$ in country $j$ and this is simply the sum of bank pairs in which banks in country $i$ lend to those in country $j$. The bank linkages are computed based on syndicated bank loans from Dealogic's Loan Analysis, ${ }^{2}$ and then rescaled by dividing by 100 . The results are summarised in Table 6. The coefficients of interaction in all models are statistically significant and have the expected positive sign. The findings suggest that GBLs play an essential role in mitigating the adverse impacts of GES on export performance. Our emphasis on the moderating role of GBL on the sanction-export survival nexus supports Peterson's discussion.

\section{Endogeneity Issue}

Up to now, we have abstracted the endogeneity issue that possibly stems from the reverse causality between GES and export survival, and omitted variables. Concerning reverse causality, as contended by Wagner (1988), a country that survives longer in foreign markets can maintain its international relationships, thus it climbs to a higher position in the global trade network. While sanctions express a country's bargaining power, a better position in the global trade network implies a strong bargaining power, and therefore influences sanction actions. Furthermore, the levels of vulnerability and leverage, which also depend on the position in the global trade network, determine the type of sanction behaviour such as unilateral or multilateral sanctions (Peterson, 2018). Concerning the omitted variables, the existence of unobservable factors such as export-oriented policies that influence both firms' survival and sanctions can lead to biased estimation.

\footnotetext{
${ }^{2}$ We thank Caballero et al. (2018) for sharing the data.
} 
Table 5. Interaction between sanctions and global value chains

\begin{tabular}{|c|c|c|c|c|c|c|c|c|c|}
\hline \multirow{3}{*}{ VARIABLES } & \multicolumn{3}{|c|}{ First-year Survivor } & \multicolumn{3}{|c|}{ Second-year Survivor } & \multicolumn{3}{|c|}{ Third-year Survivor } \\
\hline & Total GVC & Backward & Forward & Total GVC & Backward & Forward & Total GVC & Backward & Forward \\
\hline & (1) & (2) & (3) & (4) & (5) & (6) & (7) & (8) & (9) \\
\hline Sanction & $\begin{array}{l}-0.0402 \\
(0.0330)\end{array}$ & $\begin{array}{c}-0.0443 * * * \\
(0.0144)\end{array}$ & $\begin{array}{c}-0.0324 \\
(0.0340)\end{array}$ & $\begin{array}{c}-0.0466^{*} \\
(0.0248)\end{array}$ & $\begin{array}{c}-0.0313^{*} \\
(0.0167)\end{array}$ & $\begin{array}{l}-0.00407 \\
(0.0562)\end{array}$ & $\begin{array}{c}-0.0139 \\
(0.0200)\end{array}$ & $\begin{array}{c}-0.0518^{* * *} \\
(0.0193)\end{array}$ & $\begin{array}{c}-0.0224 \\
(0.0370)\end{array}$ \\
\hline GVC & $\begin{array}{c}0.00306 \\
(0.00310)\end{array}$ & $\begin{array}{c}0.0147^{* * *} \\
(0.00326)\end{array}$ & $\begin{array}{c}0.00543 \\
(0.00360)\end{array}$ & $\begin{array}{l}0.00634^{*} \\
(0.00334) \\
\end{array}$ & $\begin{array}{c}0.00964^{* * *} \\
(0.00289) \\
\end{array}$ & $\begin{array}{c}0.00345 \\
(0.00322) \\
\end{array}$ & $\begin{array}{c}0.00467 \\
(0.00292) \\
\end{array}$ & $\begin{array}{c}0.00882^{* *} \\
(0.00404)\end{array}$ & $\begin{array}{c}0.00321 \\
(0.00305) \\
\end{array}$ \\
\hline Sanction*GVC & $\begin{array}{l}0.00317 \\
(0.0235)\end{array}$ & $\begin{array}{c}0.0628^{* * *} \\
(0.0163) \\
\end{array}$ & $\begin{array}{l}0.00313 \\
(0.0515) \\
\end{array}$ & $\begin{array}{c}0.0186 \\
(0.0146) \\
\end{array}$ & $\begin{array}{l}0.0397^{*} \\
(0.0255) \\
\end{array}$ & $\begin{array}{c}-0.0350 \\
(0.0931) \\
\end{array}$ & $\begin{array}{c}-0.0157 \\
(0.0201) \\
\end{array}$ & $\begin{array}{l}0.284^{*} \\
(0.166) \\
\end{array}$ & $\begin{array}{r}-0.00752 \\
(0.0838) \\
\end{array}$ \\
\hline GDP & $\begin{array}{c}-0.00544 \\
(0.0120) \\
\end{array}$ & $\begin{array}{r}-0.00305 \\
(0.0119) \\
\end{array}$ & $\begin{array}{c}-0.00561 \\
(0.0119) \\
\end{array}$ & $\begin{array}{c}-0.00108 \\
(0.0121) \\
\end{array}$ & $\begin{array}{l}0.00113 \\
(0.0121) \\
\end{array}$ & $\begin{array}{c}-0.000489 \\
(0.0121) \\
\end{array}$ & $\begin{array}{c}-0.0320^{* *} \\
(0.0139) \\
\end{array}$ & $\begin{array}{c}-0.0307^{* *} \\
(0.0139) \\
\end{array}$ & $\begin{array}{c}-0.0316 * * \\
(0.0139) \\
\end{array}$ \\
\hline $\operatorname{lnD}$ & $\begin{array}{c}-0.0424^{* * *} \\
(0.00439)\end{array}$ & $\begin{array}{c}-0.0386 * * * \\
(0.00404)\end{array}$ & $\begin{array}{c}-0.0430^{* * *} \\
(0.00389)\end{array}$ & $\begin{array}{c}-0.0366^{* * *} \\
(0.00386)\end{array}$ & $\begin{array}{c}-0.0373 * * * \\
(0.00359)\end{array}$ & $\begin{array}{c}-0.0400 * * * \\
(0.00346)\end{array}$ & $\begin{array}{c}-0.0324^{* * *} \\
(0.00353)\end{array}$ & $\begin{array}{c}-0.0329 * * * \\
(0.00337)\end{array}$ & $\begin{array}{c}-0.0346^{* * *} \\
(0.00326)\end{array}$ \\
\hline FTA & $\begin{array}{c}-0.00125 \\
(0.00664) \\
\end{array}$ & $\begin{array}{r}-0.000415 \\
(0.00655) \\
\end{array}$ & $\begin{array}{c}-0.00203 \\
(0.00671) \\
\end{array}$ & $\begin{array}{l}0.0129 * * \\
(0.00604) \\
\end{array}$ & $\begin{array}{l}0.0128 * * \\
(0.00604) \\
\end{array}$ & $\begin{array}{c}0.0120^{*} \\
(0.00614)\end{array}$ & $\begin{array}{l}0.0134 * * \\
(0.00524) \\
\end{array}$ & $\begin{array}{l}0.0133^{* *} \\
(0.00523)\end{array}$ & $\begin{array}{l}0.0129 * * \\
(0.00531)\end{array}$ \\
\hline $\mathrm{HHI}$ & $\begin{array}{c}-0.0223 \\
(0.0170)\end{array}$ & $\begin{array}{c}-0.0252 \\
(0.0169)\end{array}$ & $\begin{array}{c}-0.0226 \\
(0.0170)\end{array}$ & $\begin{array}{c}-0.0149 \\
(0.0157)\end{array}$ & $\begin{array}{c}-0.0159 \\
(0.0156)\end{array}$ & $\begin{array}{c}-0.0143 \\
(0.0156)\end{array}$ & $\begin{array}{r}-0.00423 \\
(0.0138)\end{array}$ & $\begin{array}{c}-0.00479 \\
(0.0138)\end{array}$ & $\begin{array}{r}-0.00405 \\
(0.0138)\end{array}$ \\
\hline InValue & $\begin{array}{c}0.0141^{* * *} \\
(0.00308)\end{array}$ & $\begin{array}{c}0.0143 * * * \\
(0.00312)\end{array}$ & $\begin{array}{c}0.0142^{* * *} \\
(0.00310)\end{array}$ & $\begin{array}{c}0.0116 * * * \\
(0.00352)\end{array}$ & $\begin{array}{c}0.0121 * * * \\
(0.00359)\end{array}$ & $\begin{array}{c}0.0121 * * * \\
(0.00357)\end{array}$ & $\begin{array}{l}0.00756^{*} \\
(0.00389)\end{array}$ & $\begin{array}{c}0.00794^{* *} \\
(0.00395)\end{array}$ & $\begin{array}{c}0.00783^{* *} \\
(0.00391) \\
\end{array}$ \\
\hline Share & $\begin{array}{c}-0.163^{* * *} \\
(0.0471)\end{array}$ & $\begin{array}{c}-0.168^{* * *} \\
(0.0472) \\
\end{array}$ & $\begin{array}{c}-0.164^{* * *} \\
(0.0473) \\
\end{array}$ & $\begin{array}{c}-0.209^{* * *} \\
(0.0352) \\
\end{array}$ & $\begin{array}{c}-0.212^{* * *} \\
(0.0352) \\
\end{array}$ & $\begin{array}{c}-0.210 * * * \\
(0.0353) \\
\end{array}$ & $\begin{array}{c}-0.192 * * * \\
(0.0263) \\
\end{array}$ & $\begin{array}{c}-0.194 * * * \\
(0.0263) \\
\end{array}$ & $\begin{array}{c}-0.192 * * * \\
(0.0264) \\
\end{array}$ \\
\hline Observations & 4705 & 4705 & 4705 & 3828 & 3828 & 3828 & 3104 & 3104 & 3104 \\
\hline Number of pair & 839 & 839 & 839 & 736 & 736 & 736 & 685 & 685 & 685 \\
\hline Country FE & YES & YES & YES & YES & YES & YES & YES & YES & YES \\
\hline Year FE & YES & YES & YES & YES & YES & YES & YES & YES & YES \\
\hline R2 & 0.420 & 0.423 & 0.420 & 0.504 & 0.504 & 0.502 & 0.510 & 0.511 & 0.509 \\
\hline
\end{tabular}

Robust standard errors in parentheses; ${ }^{* *} p<0.01,{ }^{* *} p<0.05,{ }^{*} p<0.1$.

Source: own study. 
Table 6. Interaction between sanctions and global bank linkages

\begin{tabular}{|c|c|c|c|}
\hline \multirow{2}{*}{ VARIABLES } & First-year Survivor & Second-year Survivor & Third-year Survivor \\
\hline & (1) & (2) & (3) \\
\hline Sanction & $\begin{array}{c}-0.0474 * * * \\
(0.0129)\end{array}$ & $\begin{array}{c}-0.0391 * * * \\
(0.0143)\end{array}$ & $\begin{array}{c}-0.0365 * * * \\
(0.0125)\end{array}$ \\
\hline Link & $\begin{array}{l}-0.00276 \\
(0.00218)\end{array}$ & $\begin{array}{l}-0.00166 \\
(0.00202)\end{array}$ & $\begin{array}{c}-0.00202 \\
(0.00183)\end{array}$ \\
\hline Sanction*Link & $\begin{array}{c}0.0476 * * * \\
(0.0104) \\
\end{array}$ & $\begin{array}{l}0.0218^{*} \\
(0.0131) \\
\end{array}$ & $\begin{array}{c}0.0203 * * * \\
(0.00457) \\
\end{array}$ \\
\hline GVCtotal & $\begin{array}{c}0.00289 \\
(0.00304) \\
\end{array}$ & $\begin{array}{c}0.00472 \\
(0.00314) \\
\end{array}$ & $\begin{array}{l}0.00570 * \\
(0.00307) \\
\end{array}$ \\
\hline GDP & $\begin{array}{l}0.00316 \\
(0.0101) \\
\end{array}$ & $\begin{array}{l}0.00712 \\
(0.0104) \\
\end{array}$ & $\begin{array}{l}-0.0155 \\
(0.0125) \\
\end{array}$ \\
\hline $\ln D$ & $\begin{array}{c}-0.0432 * * * \\
(0.00416)\end{array}$ & $\begin{array}{c}-0.0383 * * * \\
(0.00381)\end{array}$ & $\begin{array}{c}-0.0335 * * * \\
(0.00357)\end{array}$ \\
\hline FTA & $\begin{array}{c}9.62 \mathrm{e}-05 \\
(0.00624)\end{array}$ & $\begin{array}{l}0.0123 * * \\
(0.00575) \\
\end{array}$ & $\begin{array}{l}0.0121^{* *} \\
(0.00485) \\
\end{array}$ \\
\hline $\mathrm{HHI}$ & $\begin{array}{c}-0.0258 \\
(0.0157) \\
\end{array}$ & $\begin{array}{l}-0.0130 \\
(0.0148) \\
\end{array}$ & $\begin{array}{l}0.00235 \\
(0.0134) \\
\end{array}$ \\
\hline InValue & $\begin{array}{c}0.0144 * * * \\
(0.00331) \\
\end{array}$ & $\begin{array}{c}0.0110 * * * \\
(0.00392) \\
\end{array}$ & $\begin{array}{c}0.00687 \\
(0.00428) \\
\end{array}$ \\
\hline Share & $\begin{array}{c}-0.167^{* * *} \\
(0.0428) \\
\end{array}$ & $\begin{array}{c}-0.154^{* * *} \\
(0.0432) \\
\end{array}$ & $\begin{array}{l}-0.108 * * \\
(0.0501)\end{array}$ \\
\hline Constant & $\begin{array}{c}0.713^{* *} \\
(0.305) \\
\end{array}$ & $\begin{array}{c}0.389 \\
(0.316) \\
\end{array}$ & $\begin{array}{c}0.956 * * \\
(0.381)\end{array}$ \\
\hline Observations & 5445 & 4464 & 3683 \\
\hline Country FE & YES & YES & YES \\
\hline Year FE & YES & YES & YES \\
\hline $\mathrm{R} 2$ & 0.413 & 0.474 & 0.480 \\
\hline
\end{tabular}

Robust standard errors in parentheses; ${ }^{* *} \mathrm{p}<0.01,{ }^{* *} \mathrm{p}<0.05,{ }^{*} \mathrm{p}<0.1$.

Source: own study.

The above discussions suggest that there is potential for the endogeneity issue, which may bias our estimation results. To address this issue, we apply the instrumental variable (IVs) method. We apply the location average approach proposed by Fisman and Svensson (2007). In this article, we employ the average sanction level applied to a target country by all sender countries as an instrumental variable. As revealed by Baldwin and Jaimovich (2012), this instrument is well built in the standard domino effect of tariff liberalisation. Moreover, the location average approach can minimise omitted unobservable errors related to sanction intensity (Ha et al., 2021). We also used the Global Peace Index (GPI) taken from the Institute for Economics and Peace as another instrument. Cox and Drury (2006) reveal the relationship between sanction and demographic peace. To check the validity of the instrumental variables, we conducted various endogeneity tests and report them to Table 7. All tests demonstrate that our instruments are valid and appropriate. The IV estimation results are then outlined in Table 8 . It can be seen that the effects of GES on export survival become more pronounced when the endogeneity issue is controlled. 
Table 7. Endogeneity test

\begin{tabular}{|l|c|c|c|}
\hline \multirow{2}{*}{ Sanction (First stage model) } & \multicolumn{2}{|c|}{ Coefficient } \\
\cline { 2 - 4 } & First-year Survivor & Second-year Survivor & Third-year Survivor \\
\hline Sargan $\chi^{2}$ statistics & 3.41 & 0.07 & 1.47 \\
(Over-identification test) & $(0.64)$ & $(0.783)$ & $(0.225)$ \\
\hline Anderson Canon.Corr. LM statistic & 2312.17 & 1814.08 & 1363.71 \\
(Under-identification test) & $(0.000)$ & $(0.000)$ & $(0.000)$ \\
\hline \multirow{2}{*}{ Cragg-Donald Wald F-statistic } & 4891.20 & 3958.58 & 3243.57 \\
& $(0.000)$ & $(0.000)$ & $(0.000)$ \\
\hline
\end{tabular}

Source: own study.

Table 8. IV estimation

\begin{tabular}{|l|c|c|c|}
\hline \multirow{2}{*}{ VARIABLES } & First-year Survivor & Second-year Survivor & Third-year Survivor \\
\cline { 2 - 4 } & $\mathbf{( 1 )}$ & $\mathbf{( 2 )}$ & $\mathbf{( 3 )}$ \\
\hline \multirow{2}{*}{ Sanction } & $-0.0644^{* * *}$ & $-0.0556^{* *}$ & $-0.0413^{* *}$ \\
& $(0.0242)$ & $(0.0220)$ & $0.0205)$ \\
\hline \multirow{2}{*}{ GVCtotal } & $0.00691^{*}$ & $0.00795^{* *}$ & $(0.00283)$ \\
\hline \multirow{2}{*}{ GDP } & $(0.00395)$ & $(0.00334)$ & -0.0195 \\
& -0.00533 & 0.00537 & $(0.0152)$ \\
\hline \multirow{2}{*}{ InD } & $(0.0146)$ & $(0.0138)$ & $-0.0278^{* * *}$ \\
& $-0.0368^{* * *}$ & $-0.0329^{* * *}$ & $(0.00368)$ \\
\hline \multirow{2}{*}{ FTA } & $(0.00476)$ & $(0.00415)$ & $0.0111^{*}$ \\
& 0.00363 & 0.0104 & $(0.00620)$ \\
\hline \multirow{2}{*}{ HHI } & $(0.00809)$ & $(0.00744)$ & $-0.0396^{* *}$ \\
& $-0.0462^{* *}$ & $-0.0379^{* *}$ & $(0.0162)$ \\
\hline \multirow{2}{*}{ InValue } & $(0.0191)$ & $(0.0170)$ & $0.00953^{* *}$ \\
& $0.0164^{* * *}$ & $0.0116^{* * *}$ & $(0.00383)$ \\
\hline \multirow{2}{*}{ Share } & $(0.00394)$ & $(0.00341)$ & $-0.315^{* * *}$ \\
\hline \multirow{2}{*}{ Constant } & $-0.304^{* * *}$ & $-0.335^{* * *}$ & $(0.0290)$ \\
\hline Observations & $(0.0430)$ & $(0.0343)$ & $1.078^{* *}$ \\
\hline Country FE & $0.939^{* *}$ & 0.439 & $(0.461)$ \\
\hline Year FE & $(0.442)$ & $(0.420)$ & 2290 \\
\hline R2 & 3588 & 2916 & YES \\
\hline Robust & YES & YES & 0.530 \\
\hline
\end{tabular}

Robust standard errors in parentheses; *** $\mathrm{p}<0.01, * * \mathrm{p}<0.05, * \mathrm{p}<0.1$.

Source: own study.

\section{CONCLUSIONS}

This article uses a database of 66 countries during the 1997-2014 period to investigate the association between global sanctions and export survival. By employing the structural gravity model, we indicate the adverse effects of global sanctions on export survival. The marginal effects of sanctions become stronger if there is a longer physical or "soft" distance between the sender and target country. By contrast, our study suggests two channels, GVCs and GBLs, through which exporters in target countries can alleviate the harmful effects of sanctions.

Our empirical findings are expected to provide some vital implications for both economists and policy makers to help exporters survive better and maintain international trade when confronting the threat of economic sanctions. Our findings show that being a part of global linkages makes the consequence of sanctions less significant. Regarding the sanctioning states, our findings provide implications to improve the success of economic sanctions, especially if the target countries have a good connection 
with others through trade and capital investments. In particular, other policies that aim to disrupt global linkages such as global supply chains, global banking networks and global investments, should be implemented simultaneously with economic sanctions. In this spirit, the combination of different policies could make economic sanctions more effective. Regarding the sanctioned states, these countries should become more involved in global linkages to alleviate economic hardship due to economic sanctions. In addition, the governments of target countries should encourage firms to indirectly invest in the senders through their partners and subsidiaries. These policies could be considered as a way to ease tensions between sanctioning and sanctioned countries.

Although we do our best to control all the potential issues, our study still contains limitations that need to be improved upon in further research. Firstly, we only focus on the direct effects of sanctions on the target countries, while their spillover effects on third parties that are either non-embargoed products or non-sanctioning countries, as suggested by Crozet and Hinz (2017), suggest more interesting policy implications. Secondly, other channels through which the impacts of economic sanctions may be mitigated should be considered. Thirdly, the effects of sanctions on other types of international transactions such as the formation of global investment and banking networks, or on other dimensions like welfare and entrepreneurship in the target countries should be investigated. Future research should take these issues into account to shed more light on the effects of sanctions.

\section{REFERENCES}

Ahn, D.P., \& Ludema, R.D. (2020). The sword and the shield: the economics of targeted sanctions. European Economic Review, 130, 103587. https://doi.org/10.1016/j.euroecorev.2020.103587

Ali, M.M., \& Shah, I. (2000). Sanctions and childhood mortality in Iraq, Lancet, 355, 1851-1856. https://doi.org/10.1016/S0140-6736(00)02289-3

Baldwin, E., \& Jaimovich, D. (2012). Are free trade agreements contagious?. Journal of International Economics, 88(1), 1-16. https://doi.org/10.1016/j.jinteco.2012.03.009

Barry, C.M., \& Kleinberg, K.B. (2015). Profiting from Sanctions: Economic Coercion and US Foreign Direct Investment in Third-Party States. International Organization, 69(04), 881-912. https://doi.org/10.1017/S002081831500017X

Bellora, C., \& Fontagné, L. (2020). Shooting oneself in the foot? Trade war and global value chains. CEPII Working Paper No 2019-18. http://dx.doi.org/10.2139/ssrn.3526944

Besedes, T., \& Prusa, T.J. (2006a). Ins, outs and duration of trade. Canadian Journal of Economics, 39(1), 266-95. https://doi.org/10.1111/j.0008-4085.2006.00347.x

Besedes, T., \& Prusa, T.J. (2006b). Product differentiation and duration of US import trade. Journal of International Economics, 70(2), 339-58. https://doi.org/10.1016/j.jinteco.2005.12.005

Besedes, T., \& Prusa, T.J. (2011). The role of extensive and intensive margins and export growth. Journal of Development Economics, 96(2), 371-379. https://doi.org/10.1016/j.jdeveco.2010.08.013

Biglaiser, G., \& Staats, J.L. (2010). Do Political Institutions Affect Foreign Direct Investment? A Survey of US Corporations in Latin America. Political Research Quarterly, 63, 508-522. https://doi.org/10.1177/1065912909331428

Brenton, P., Pierola, M.D., \& von Uexkull, E. (2009). The life and death of trade flows:

understanding the survival rates of developing-country exporters. International Trade, Distribution and Development: Empirical Studies of Trade Policies. Singapore: World Scientific Publishing.

Chen, X., \& Garcia, R.J. (2016). Economic sanctions and trade diplomacy: Sanction-busting strategies, market distortion and efficacy of China's restrictions on Norwegian salmon imports. China Information, 30(1), 2957. https://doi.org/10.1177/0920203X15625061

Corcoles, D., Diaz-Mora, C., \& Gandoy, R. (2015). Export survival in global value chains. The World Economy, 38 (10), 1526-1554. https://doi.org/10.1111/twec.12249

Cortright, D. \& Lopez, G. (2000). The sanctions decade: Assessing UN strategies in the 1990s. Boulder, CO: Lynne Rienner.

Cox, D.G., \& Drury, A.C. (2006). Democratic sanctions: Connecting the democratic peace and economic sanctions. Journal of Peace Research, 43(6), 709-722. https://doi.org/10.1177/0022343306068104 
Crozet, M. \& Hinz, J. (2017). Friendly Fire: The Trade Impact of the Russia Sanctions and Counter-Sanctions. Kiel Working Paper.

Daponte, B., \& Garfield, R. (2000). The effect of economic sanctions on the mortality of Iraqi children prior to the 1991 Persian Gulf War, American Journal of Public Health, 90(4), 546-552. https://doi.org/10.2105/ajph.90.4.546

Diaz-Mora, C., Gandoy, R., \& Gonzalez-Diaz, B. (2018). Strengthening the stability of exports through GVC participation: The who and how matters. Journal of Economic Studies, 45(3), 610-637. https://doi.org/10.1108/JES04-2017-0106

Felbermayr, G., Kirilakha, A., Syropoulos, C., Yalcin, E., \& Yotov, Y.V. (2020). The global sanctions data base. European Economic Review, 129, 1-23. https://doi.org/10.1016/j.euroecorev.2020.103561

Fisman, R., \& Svensson, J. (2007). Are corruption and taxation really harmful to growth? Firm level evidence. Journal of Development Economics, 83(1), 63-75. https://doi.org/10.1016/j.jdeveco.2005.09.009

Folch, A.E. (2010). Economic Sanctions and the Duration of Civil Conflicts. Journal of Peace Research, 47(2) 129141. https://doi.org/10.1177/0022343309356489

Funke, M., \& Ruhwedel, R. (2001). Export variety and export performance: Empirical evidence from East Asia. Journal of Asian Economics, 12, 493-505. https://doi.org/10.1016/S1049-0078(01)00100-2

Garfield, R. (2002). Economic sanctions, humanitarianism and conflict after the Cold War, Social Justice, 29(3), 94-107. https://www.jstor.org/stable/29768138

Ha, L.T., Nam, P.X., \& Thanh, T.T. (2021). Effects of Bribery on Firms' Environmental Innovation Adoption in Vietnam: Mediating Roles of Firms' Bargaining Power and Credit and Institutional Constraints. Ecological Economics, 185, 107042. https://doi.org/10.1016/j.ecolecon.2021.107042

Hale, G. (2012). Bank relationships, business cycles, and financial crises. Journal of International Economics, 88(2), 312-325. https://doi.org/10.1016/j.jinteco.2012.01.011

Hufbauer, G., Schott, J., Elliott, K.A., \& Oegg, B. (2009). Economic sanctions reconsidered: History and current policy. Washington, DC: Peterson Institute for International Economics.

IMF (2009). Sustaining the recovery. World Economic and Financial Survey, Washington, DC: International Monetary Fund.

Janeba, E. (2002). Attracting FDI in a Politically Risky World. International Economic Review, 43, 1127-1155. https://doi.org/10.1111/1468-2354.t01-1-00051

Jensen, N.M. (2008). Political Risk, Democratic Institutions, and Foreign Direct Investment. The Journal of Politics, 70, 1040-1052. https://doi.org/10.1017/S0022381608081048

Mao, H., \& Görg, H. (2020). Friends like this: The impact of the US-China trade war on global value chains. The World Economy, 43(7), 1776-1791. https://doi.org/10.1111/twec.12967

Niepmann, F., \& Schmidt-Eisenlohr, T. (2017). International trade, risk and the role of banks. Journal of International Economics, 107, 111-126. https://doi.org/10.1016/j.jinteco.2017.03.007

Obashi, A. (2010). Stability of production networks in East Asia: Duration and survival of trade. Japan and the World Economy, 22 (1), 21-30. https://doi.org/10.1016/j.japwor.2009.06.002

Parteka, A., \& Wolszczak-Derlacz, J. (2017). Workers, firms and task heterogeneity in international trade analysis: An example of wage effects of trade within GVC. Entrepreneurial Business and Economics Review, 5(2), 9-25. https://doi.org/10.15678/EBER.2017.050201

Peksen, D., \& Drury, A.C. (2010). Coercive or corrosive: The negative impact of economic sanctions on democracy. International Interactions, 36(3), 240-264. https://doi.org/10.1080/03050629.2010.502436

Peksen, D. (2019). When do imposed economic sanctions work? A critical review of the sanctions effectiveness literature. Defence and Peace Economics, 30(6), 635-647. https://doi.org/10.1080/10242694.2019.1625250

Peterson, T.M. (2020) Reconsidering economic leverage and vulnerability: Trade ties, sanction threats, and the success of economic coercion. Conflict Management and Peace Science, 37(4), 409-429. https://doi.org/10.1177/0738894218797024

Poelhekke, S. (2015). Do global banks facilitate foreign direct investment?. European Economic Review, 76, 2546. https://doi.org/10.1016/j.euroecorev.2015.01.014

Romalis, J. (2004). Factor Proportions and the Structure of Commodity Trade. American Economic Review, 94(1), 67-97. https://doi.org/10.1257/000282804322970715 
Stirbat, L., Record, R., \& Nghardsaysone, K. (2015). The experience of survival: Determinants of export survival in Lao PDR. World Development, 76, 82-94. https://doi.org/10.1016/j.worlddev.2015.06.007

Türkcan, K., \& Saygili, H. (2019). Global production chains and export survival. Eastern European Economics, 57(2), 103-129. https://doi.org/10.1080/00128775.2018.1539335

Wagner, R.H. (1988). Economic interdependence, bargaining power, and political influence. International Organization, 42(3), 461-483. https://doi.org/10.1017/S0020818300027703

Zhu, X., Liu, B., \& Wei, Q. (2019). Does participation in global value chains extend export duration?. Review of Development Economics, 23 (3), 1282-1308. https://doi.org/10.1111/rode.12588

\section{Appendix: Definition of export survival rate}

- Entrant $t_{\mathrm{t}}$ a firm that does not export in year $\mathrm{t}-1$ but exports in year $\mathrm{t}$.

- Survivor ${ }_{\mathrm{t}}$ : a firm that does not export in year $\mathrm{t}-1$ but exports in both years $\mathrm{t}$ and $\mathrm{t}+1$.

- 2-Year Survivor $r_{t}$ a firm that does not export in year $t-1$ but exports in years $t, t+1$ and $t+2$.

- 3-Year Survivor ${ }_{t}$ : a firm that does not export in year $t-1$ but exports in years $t, t+1, t+2$ and $t+3$.

FSUR $_{\mathrm{t}}=$ Survivor $_{\mathrm{t}} /$ Entrant $_{\mathrm{t}}$

SSUR $_{\mathrm{t}}=2-$ Year Survivor $_{\mathrm{t}} /$ Entrant $_{\mathrm{t}}$

FSUR $_{\mathrm{t}}=3$-Year Survivor $\mathrm{H}_{\mathrm{t}} /$ Entrant $_{\mathrm{t}}$

Table A.1. Countries in the sample

\begin{tabular}{|l|c|l|c|l|c|c|c|}
\hline \multicolumn{1}{|c|}{ Country } & \% & \multicolumn{1}{|c|}{ Country } & \% & \multicolumn{1}{c|}{ Country } & \% & \multicolumn{1}{c|}{ Country } & \% \\
\hline United Arab Emirates & 1.50 & Chile & 1.58 & Spain & 1.97 & India & 1.79 \\
\hline Argentina & 1.62 & China & 1.86 & Estonia & 1.33 & Ireland & 1.71 \\
\hline Australia & 1.79 & Colombia & 1.23 & Finland & 1.46 & Iceland & 0.65 \\
\hline Austria & 1.68 & Costa Rica & 0.96 & France & 2.24 & Israel & 1.08 \\
\hline Belgium & 2.02 & Czechia & 1.68 & United Kingdom & 2.07 & Italy & 1.99 \\
\hline Bulgaria & 1.54 & Germany & 2.11 & Greece & 1.44 & Japan & 1.85 \\
\hline Bahamas & 1.05 & Denmark & 1.81 & Hong Kong & 1.89 & Korea & 1.67 \\
\hline Brazil & 1.94 & Dominican Republic & 0.82 & Honduras & 0.47 & Lithuania & 1.15 \\
\hline Canada & 2.03 & Ecuador & 0.88 & Hungary & 1.74 & Luxembourg & 1.88 \\
\hline Switzerland & 1.90 & Egypt & 1.32 & Indonesia & 1.48 & Latvia & 1.25 \\
\hline Country & $\%$ & Country & $\%$ & Country & \% & & \\
\hline Morocco & 1.00 & Poland & 1.67 & Turkey & 1.47 & & \\
\hline Mexico & 1.59 & Portugal & 1.71 & Ukraine & 1.15 & & \\
\hline Malaysia & 1.61 & Romania & 1.50 & Uruguay & 1.35 & & \\
\hline Netherlands & 2.30 & Russian Federation & 1.71 & United States & 2.33 & & \\
\hline Norway & 1.71 & Singapore & 1.75 & Venezuela & 1.33 & & \\
\hline New Zealand & 1.17 & El Salvador & 0.55 & South Africa & 1.71 & & \\
\hline Pakistan & 0.87 & Slovenia & 1.06 & & & & \\
\hline Panama & 1.48 & Sweden & 1.60 & & & & \\
\hline Peru & 1.50 & Thailand & 1.64 & & & \\
\hline Philippines & 1.25 & Trinidad and Tobago & 0.55 & & & \\
\hline
\end{tabular}

Source: own study. 


\section{Author}

\section{Le Thanh $\mathrm{Ha}$}

PhD in Policy Analysis from National Graduate Institute for Policy Studies. He is currently a lecturer at the Faculty of Economics, National Economics University. His main research areas are macroeconomic analysis, international economics, financial stability, and corporate performance analysis.

Correspondence to: Dr. Le Thanh Ha, National Economic University, Faculty of Economics, 207 Giai Phong, Hanoi, Vietnam. e-mail: halethanh.kt@gmail.com

ORCID (1) http://orcid.org/0000-0002-4517-9097

\section{Acknowledgements and Financial Disclosure}

I would like to thank the anonymous referees for their useful comments, which allowed to increase the value of this article.

\section{Conflict of Interest}

The author declares that the research was conducted in the absence of any commercial or financial relationships that could be construed as a potential conflict of interest.

\section{Copyright and License}

This article is published under the terms of the Creative Commons

Attribution - NoDerivs (CC BY-ND 4.0) License

http://creativecommons.org/licenses/by-nd/4.0/ 